\title{
World Problematique
}

Hugo Thiemann clarifies the Club of Rome's role as catalyst in formulating values and defining goals for society.

Governments must change from their present preoccupation with growth of Gross National Products, if the human species is to survive without falling into a state of worthless existence. Physicists should be induced to move from non-orientated or basic research on to projects aimed at meeting the needs of global society. Too many scientists are simply engaged in paper proliferation without a sense of responsibility to society. These challenging views were expressed by Hugo Thiemann *, DirectorGeneral of Battelle, Geneva, and a founder-member of the Club of Rome, in an interview with Europhysics News Editor, Alex H. Crawford.

The MIT study of the 'World Problematique', as defined by the Club of Rome in 1970, and resulting recently in The Limits to Growth ${ }^{1}$ provided a good starting-point. The book itself is having world-wide repercussions at decision-making level, according to Thiemann.

\section{The Club of Rome}

Thiemann described how the Club of Rome was founded in 1968 by Aurelio Peccei, of Fiat, Olivetti and Italconsult (an agency for economic and engineering organization), as an informal, multi-national and non-political group. They had agreed that current trends in the world techno-economic system were pointing towards a highlydangerous situation. Peccei, Thiemann and Alexander King (Head of the Science and Technology Division of OECD) and other members of the Club of Rome contacted individuals in other developed countries (Canada, Japan, USA, USSR) and found that they were all aware of the menace ahead.

The Club's first project on The Predicament of Mankind ${ }^{2}$ emphasized the interdependence of variables in the techno-economic system, its dynamic

\footnotetext{
* Hugo Thiemann is an Individual Ordinary Member of EPS. Battelle, Geneva, is an Associate Member and provides many services to the Society, as well as making a significant contribution to the accom-
} modation of the Main Secretariat. nature, and its global scope. By June 1970 at the Club's meeting in Bern, Thiemann said, preliminary goals had been set, a survey of methodologies completed, and the statement of the 'World Problematique' prepared. But still the methods seemed vague, and it was realised that, for the programme to become more concrete, great intellectual effort would be required; that would need financial resources which the Club of Rome could not provide as an informal group. The Executive Committee now includes E. Pestel, S. Okita, and C.L. Wilson, as well as A. Peccei, A. King and $H$. Thiemann, and The Club of Rome is registered as an Association in Geneva.

\section{World Dynamics}

At the Bern meeting, J.W. Forrester (MIT) proferred the systems approach that he had developed for industrial and urban dynamics. The Club's Executive Committee travelled to MIT for 10 days the next month to examine the methodology proposed. Forrester successfully convinced them that the first model should have only five parameters - relating to population and capital (growth factors) and natural resources, pollution and land (limiting factors) in a one-year trial. The model that Forrester used was described in his book ${ }^{3}$. Whilst Thiemann applauded Forrester's courage in tackling the Problematique with such a simple model, he made it clear that the Club of Rome were all aware of its limitations and considered it as only the first step. The underlying, and often subjective, assumptions were to be explored more deeply and more detailed investigations into the dynamics of major sub-systems like population, pollution, capital investment, and agriculture were to be carried out by an international team under the leadership of Dennis L. Meadows.

\section{The Limits to Growth}

For any book on techno-economics to be published in 10 languages within 10 months is a formidable achievement - a credit to its particular relevance to global problems. Thiemann believed that the enormous impact of The Limits of Growth was due to its highly visual and convincingly graphic display of computer runs. Up till now, books in that field had been mainly semantic exercises and could not hold the reader's attention like The Limits to Growth.

Thiemann did point out that there had been much popular misconception over the status of the 'models' used, but he was sure that physicists would find the approach appealing. However, he was ready to admit that the modelbuilder had a significant influence on the results in the choice of how variables were to be related. This subjectivity necessarily meant that the Problematique was illuminated from one direction only and that there was still much in the dark for which further studies would be needed.

To gauge the full import of the MIT work, Thiemann recommended that technical people should consult the two-volume report to appear in late 1972 in which the assumptions were fully explained and where the data from which the model constructed results were revealed. The data had come mainly from agencies of the United Nations and Thiemann acknowledged that their co-operative support had been most beneficial to the project.

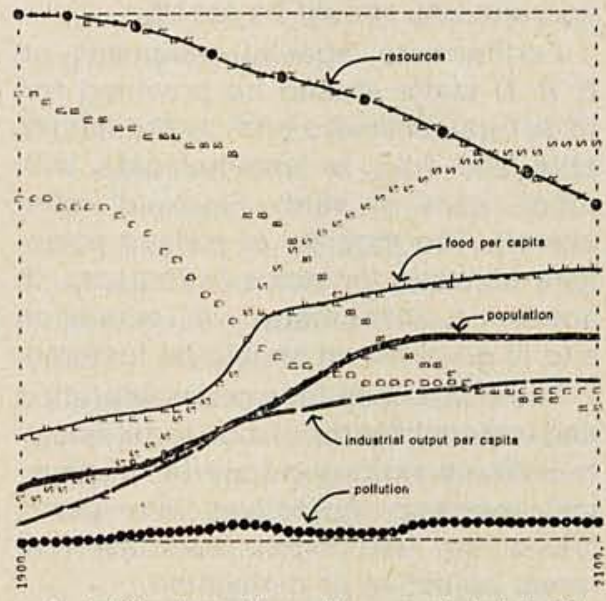

A stabilized world model as projected in The Limits to Growth. In 1975 the birth rate is reduced to two per family. Industrial capital investment reduced, pollution suppressed. 


\section{Club of Rome as catalyst}

The Club of Rome, Thiemann explained, looked upon the work it had sponsored at MIT as a catalytic agent. The world-wide response to The Limits to Growth was encouraging. Already the Japanese government, perhaps because of the particular relevance to their over-populated, under-resourced country, had started more detailed studies. The Club of Rome hoped that the emphasis by governments would turn from 'growth' to 'progress towards stability', which necessarily meant controlled growth in future.

As the Director-General of Battelle in Geneva, Thiemann believed that the consultations that the Club of Rome had had with decision-makers throughout the world had been an additional element in constructing his research policy. He considered that political, and even industrial research, timescales were not sufficiently longterm. It was essential that today's research must be influenced by the knowledge that in 20-30 years the world population could well have doubled. Whilst research policy was not an overt parameter in the MIT models, only the applications of advanced research could bring about the changes in parameters that would set the system on a course for stability.

That many institutions were concerned to predict the future in specific areas was a sign of the unrest that the Club of Rome had also detected. Many of these institutions were influenced by the Club's activities - mainly due to the contribution by Peccei, as the Club's 'engine'.

\section{Physicists and the World Problematique}

The Club of Rome's aims to formulate new values and to define goals for society were of interest to physicists and their research organizations, Thiemann maintained.

In the past, research had been aimed at understanding in the belief that it would help mankind. After a period of technological evolution based on this assumption, that belief was clearly not borne out by experience. Now, there was a serious conflict developing between planetary dimensions and population, so that physicists should change to consider future needs. Science policy should be guided by preservation of the biosphere. Perhaps this change would require physicists to become less arrogant and to show more humility. In many countries, there were now sufficient physicists, but without a sense of responsibility, since there was too much non-orientated research. However, other countries, like the USSR, still put efforts into increasing the numbers of scientific personnel. But, in those countries where the expenditure on physics was high enough in relation to GNP, more emphasis on project research was needed.

Thiemann urged that physicists should not look upon themselves as instruments in the research machinery of their laboratories. They should address themselves to the essential problems that faced the world today.

\section{Deep changes}

The Club of Rome had the general objective of helping to re-think and reformulate values and to define broad goals for society, and Thiemann saw that their initial studies heralded deep changes.

As the population continued to grow, there would be more and more need for individual discipline. Competition would be reduced as a result, and restrictions would increase. Companies would no longer emphasize growth as the sole criterion of success. Governments would recognize that other elements besides GNP growth were essential for well-being and a constructive approach to the future would arise.

\section{References}

1 MEADOWS, D.H., MEADOWS, D.L., RANDERS, J., and BEHRENS, W.W., The Limits to Growth (Universe Books, New York, and Earth Island, London) 1972.

There are now translations available of The Limits to Growth :

Dutch :

MEADOWS D., Rapport van de Club van Rome 'De grenzen aan de groei' (Uitgeverij Het Sprectrum N.V., Utrecht/Antwerpen) 1972

French :

Halte à la Croissance (Editions Fayard) 1972

\section{German :}

MEADOWS, D. 'Die Grenzen des Wachstums' Bericht des Club of Rome zur Lage der Mensckheit (Deutsche Verlangsanstalt Stuttgart) 1972

Italian :

I LIMITI DELLO SVILUPPO rapporto redatto del gruppo del MIT per il progetto del Club di Roma sui dilemmi dell umanita (Edizioni Scientifiche e Tecniche Mondatori) 1972

2 PECCEI, A. The Predicament of Mankind (Aldo Palazzo, Milan) 1970

3 FORRESTER, J.W. World Dynamics (Wright-Allen Press, Inc, Cambridge, Mass. 02142, USA) 1971.

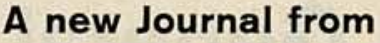 North-Holland}

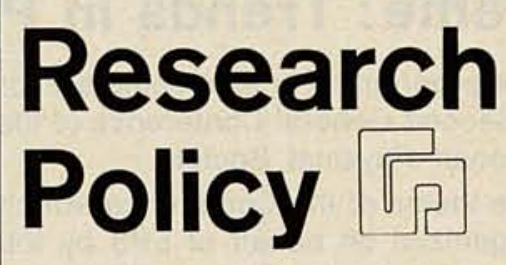

A journal devoted to research policy, research management and planning.

Editors :

C. FREEMAN, T.C. SINCLAIR,

R. COENEN, H. KRAUCH

Industrial Editors

J.G.D. CARPENTER, K.-H. STANDKE

In industrial research nowadays the main problem is not so much to manage research, but how to determine its appropriate volume and scope, how to bring it in line with the long-term planning of the company and how to integrate it with other operations. In government research policy, the key question is how to determine priorities. The new journal, RESEARCH POLICY, deals with both these problems.

The journal publishes papers both by those involved in "science policy" decisions and by independent analysts and critics, which results in a combination of theoretical writing and case studies. RESEARCH POLICY concentrates on European problems and European $R$ \& $D$ experience. The Editors belong to two leading European academic groups involved in full-time studies of research policy: the Jeidelberg Studiengruppe für Systemforschung and the University of Sussex Policy Research Unit.

\section{CONTENTS :}

Volume 1, Number 1 :

H. G. B. CASIMIR, Industries and academic freedom. P. M.S JONES, Lessons from the objective appraisal of programmes at the national level-implications of criteria and policy. H. KRAUCH, Priorities for research and technological development. C. SINCLAIR, The incorporation of health and welfare risks into incorporation of health and welfars The importance of graph theory in research planning. J. LANGRISH, Innovation in pharmaceuticals.

Volume 1, Number 2 :

B. VALENTINE, Obstacles to space cooperation : Europe and the post-Apollo experience. N. K. GARDNER, The appraisal and control of complex development projects. $R$. COENEN The use of technological forecasts in government planning. P. JERVIS, Innovation in electron-optical instruments - two British case histories.

Publication is in four issues per year. The subscription price is Dfl. 91.00 or about US $\$ 27.00$ per volume. Orders and requests for free examination copies and further information may be sent to

\section{NORTH}

Journal Division

P.O. Box 211,

Amsterdam, The Netherlands 